\title{
The Warrior Tradition and the Masculinity of War
}

\author{
ALI A. MAZRUI \\ The University of Michigan, Ann Arbor, U.S.A.
}

\begin{abstract}
A
T THE ANNUAL meeting of the Organization of African Unity held in Kampala in July 1975, Field Marshal Idi Amin drew attention to the presence of women in a special "suicide squad of the Ugandan Armed Forces." The question arose whether African women were about to play a bigger role in African military establishments. If this were to happen, how would it affect the status of women in African societies? And how does modern military technology relate to that process?

In cultures which are otherwise vastly different, the role of the warrior has been reserved for men. "Our sons are our warriors." This is virtually universal. (Israel is no exception, in spite of contrary appearances.)

Again, in cultures which are otherwise vastly different, crimes of violence have been disproportionately committed by men. The jails of the world bear solemn testimony to the basic masculinity of violent crime.

Is there a connection between this masculinity of violent crime and the preponderant masculinity of the military profession? The barracks and the prisons have a majority of men. Is this link between warriorhood and Mafiahood accidental? Or are there organic interconnections between the two?
\end{abstract}

\section{On Violence and Masculinity}

Images of valour, courage, endurance, and maturity have, in different societies, been intimately related to the role of the male in social and military affairs. Sexual division of labour has been both a cause and an effect of a range of social symbols defining boundaries of propriety and congruence. We have discussed this in a related context of the warrior tradition in relation to the origins of the State.

Especially pertinent for politics and war is a historic link between manliness and capacity for violence. Nothing illustrates this more poignantly than the sexual ambivalence of at least one major prophet of non-violence in modern history. In this ambivalence we see that link between masculinity and martial prowess.

In his psychological study of Mahatma Gandhi, Erik H. Erikson refers to 
Gandhi's tendency to see himself as half man and half woman, and his aspiration to acquire motherly qualities. Factors identified with Gandhi's bisexual state of mind range from his love for homespinning, traditionally women's work, to his self-description as a widow when a man dear to him died. We shall return to Gandhi's case later in this paper. We know that his renunciation of sexual activity, combined with a motherly interest in a young girl's physical development, added to the widespread speculation about Gandhi's psychological orientation with regard to sex.

\begin{abstract}
"He undoubtedly saw a kind of sublimated maternalism as part of the positive identity of a wholc man, and certainly of a homo religiosus. But by then all overt phallicism had become an expendable, if not a detestable matter to him. Most men, of course, consider it not only unnecessary, but in a way indignant, and even irreverent, to disavow a small god-given organ of such singular potentials; and they remain deeply suspicious of a sick element in such sexual self-disarmament. And needless to say, the suspicion of psychological self-castration becomes easily linked with the age-old propensity for considering the renunciation of armament and abandonment of malehood."1
\end{abstract}

Erikson goes on to suggest in passing that increasing the mechanization of warfare would continue to decrease the equation of manliness with martial qualities. The move from the spear to the intercontinental ballistic missile amounts to some extent to the demasculation of warfare. Face to face warfare makes greater demands on individual courage than does destruction by remote control. Gandhi's nonviolence, linked to Gandhi's sexual renunciation, was a simultaneous renunciation of both the spear and the penis. In Erikson's words:

"Here, too, Gandhi may have been prophetic; for in a mechanized future the relative devaluation of the martial model of masculinity may well lead to a freer mutual identification of the two sexes."'

Africa still has many societies that are within a combat culture of the spear. In such societies killing is a confrontation between individuals, and a man tests his manliness within a spear-throw of another. In such cultures martial and sexual qualities become virtually indistinguishable for the male of the species. Eligibility for marriage is sometimes tied to experience in killing - just as the war hero in developed technological societies continues to enhance his sexual appeal. There are of course differences of scale in the killing between a culture of the spear and a culture of bombs falling from B-52s. And the purposes of the violence may be intelligible to one culture and bizarre to another. What we do know is that within the culture of the spear, the effort is more deeply personal. The bridegroom revels in having known moments of violence and danger.

Colin M. Turnbull was once looking at a Dodo tribesman called Lemu, and reflected on issues of this kind in a comparative perspective.

1 Erikson, Gandhi's Truth: On the Origins of Militant Violence (New York: W. W. Norton, 1969) pp. 402-403.

2 Ibid. p. 403. 
"Lemu's shoulders were covered with rows of weals left by cicatrization. These are cut to show the number of people you have killed, and are an indispensable prerequisite to marriage. Lemu could look pretty fierce, if all you looked at was the rows of scars, his powerful body proudly bare except for the cloak flying in the breeze, and a string of ivory beads. His ears were pierced and lined with colored seeds, though, and he often wore a tuft of antelope hair on top of his head, and his smile and his eyes were warm and gentle like those of the rest of his people. His spear was for the protection of his cattle and his family, and it was difficult to think of Lemu wishing harm to anyone."

And then, bringing home this mysterious relationship between violence and sociability, Turnbull goes on to say the following of Lemu:

"He probably wished no harm at all even to those he killed, but faced with the choice of the life of a Turkana or that of himself and perhaps those of his wife and children, he made the same choice that most of us would make, without trying to justify it in the noble terms with which we justify our essays at mass murder.'3

Lemu belonged to a combat culture still distant from mass destruction. $\mathrm{He}$ was also an African untouched either by Gandhism or by Euro-Christian inhibitions and tendencies. We shall return later to the softening and demasculating consequences of Christianity in Africa. What we should note from the outset is the interplay between martial and sexual prowess in man's ancestral heritage.

The interrelationship between sexual maturity and military manhood has had wider political consequences within Kikuyu political culture. Circumcision ceremonies involving the "shaping" of the penis were also ceremonies of initiation into the virtues of endurance and valour. The spear also featured more explicitly in initiation ceremonies of a traditional kind. Kenyatta tells us about the paramount resolution of young Kikuyu boys on being initiated by ancient custom. They used to say in courageous affirmation:

"We brandish our spear, which is the symbol of our courageous and fighting spirit, never to retreat or abandon our hope, or run away from our comrades."4

In the Mau Mau insurrection, the Kikuyu tendency to link sexual symbolism with martial symbolism continued in an even more elaborate fashion. Josiah Kariuki, who was later to be a Minister in the Kenya government took the Mau Mau Batuni oath in the 1950s to fight on the side of the rebels. He stood naked, his penis pushed through a hole in the thorax of a goat, while he solemnly swore not to hesitate in the obligation to kill should it be necessary.

Some of the mixed symbolism of sexual and martial elements which were characteristic of Mau Mau became subjects of wide controversy. The mixture of sexual and martial ceremonies revolted some sections of international opinion, and convinced them that the movement was not nationalistic but atavistic and primitive. Pre-eminent among the controversial Mau Mau symbolism was the

3 Colin M. Turnbull, The Mountain People (New York: Simon and Schuster, 1972) pp. 104105.

4 Jomo Kenyatta gives a version of this story in his anthropological book about the Kikuyu, Facing Mount Kenya (first published in 1938) (London: Secker \& Warburg, 1959), p. 199. 
use of female menstrual blood, sometimes swallowed by the men in the oathing ceremonies. ${ }^{5}$

Some of the details of these ceremonies have in fact been disputed by those who took part in them. For our purposes in this paper it suffices that an elaborate intermixture between sexual and martial symbolism formed part of the foundation of the Mau Mau movement. ${ }^{6}$

\section{Political Masculinity in an African Empire}

The Kikuyu - as well as the Dodo, the Turkana, the Ik, etc. - are all among the less centralized of the societies of Eastern Africa. The Amhara, who ruled Ethiopia, are among the most centralized and elaborately institutionalized of the peoples of that part of the continent. The theme of masculinity as capacity to kill continues in the culture of the Amhara and the Empire they ruled. The society is on the one hand deeply Christianized, and on the other continues to have a premium placed on martial virtues. Donald N. Levine tells about the place of the purposeful cultivation of ferocity in the process of socializing and educating young people. The Amhara youth develops skills in versification, especially of the kind which is declaimed in order to inflame the blood of the warrior. Young people memorize lines of aggressive assertion, many of which glorify the warrior and the act of killing.

"Kill a man! Kill a man! It is good to kill a man!

One who has not killed a man moves around sleepily."

Levine cites an anecdote. A provincial school teacher, a boy of about twenty, was walking with Levine and another Ethiopian teacher in the countryside in Ethiopia one afternoon. Levine suggests that the mountain breeze and the rugged landscape might have gone to the head of the young teacher, for he suddenly exclaimed to his fellow:

"We are Ethiopians. Let us kill something. Let us kill a man or a wild beast."?

Levine sometimes sees too much in rhetorical bravado. But although hyperbolic in some of his interpretations, Levine is persuasive in the central thesis that "For the Amhara the virtues of the male are the virtues of the soldier." 8

5 J. M. Kariuki, Mau Mau Detainee (London: Oxford University Press, 1963). Consult also my review of his book entitled, "On Heroes and Uhuru-Worship," Transition (Kampala), 1963.

6 Idi Amin, who later became President of Uganda, fought the Mau Mau insurrectionists as a member of the King's African Rifles. For the masculine inage of Amin himself consult Mazrui, "The Militarization of Charisma: An African Perspective," paper presented at 9th World Congress of the International Political Science Association, Montreal, August 19 to $26,1973$.

7 Donald N. Levine, "The Concept of Masculinity in Ethiopian Culture," The International Joumal of Social Psychiatry, Vol. XII, No. 1, 1966, pp. 18-20.

8 Ibid., p. 18. Philip Attlee gives us a light-hearted fictional dramatization of one's first encounter with the stone phalli of Michichi in Ethiopia. "The length of the grassy glade was broken by what seemed jutting, slanting, fallen, and erect stone cylinders. We paused 
In some African societies the expansion of economic and political opportunities for young people has resulted in the decline of the prestige of the profession of combat as such. But in Ethiopia the prestige of the military hero continues to exercise considerable influence on the imagination of young people. A study some years ago on Ethiopian student conceptions of culture heroes discovered that about ninety percent of the students tested "showed a preference for the 'military man' as their 'culture hero'."'

Levine himself also conducted research among Ethiopian students and discovered that military virtues were the qualities most appreciated in Ethiopian historical figures of the past. But in spite of the persistence of martial sentiments in a large part of the student population, Levine discovered that those who reached the upper grades of the educational system "no longer look upon military activity as sanguinely as do their traditional counterparts." The following two tables provide useful comparative perspectives in this connection. ${ }^{10}$

Across the border is Somalia. The Somali are radically different in political organization and social orientation from the Amhara. Politically and diplomatically there is also considerable tension between the Somali and the Amhara. But one cultural factor that they do have in common is the mystique of purposeful ruthlessness as a manly virtue where the occasion arises. This is the central element within what I. M. Lewis calls "the martial character of the traditional Somali society where the display of force, however brutal and merciless, is

Table 1

Attitudes of Ethiopian Students to War

\begin{tabular}{lcccc} 
& & \multicolumn{3}{c}{ War is } \\
\cline { 3 - 5 } & $\mathcal{N}$ & $\begin{array}{c}\text { Needless and } \\
\text { Preventable } \\
\%\end{array}$ & $\begin{array}{c}\text { Necessary } \\
\text { Evil } \\
\%\end{array}$ & $\begin{array}{c}\text { Sometimes } a \\
\text { good thing } \\
\%\end{array}$ \\
\hline Secondary School Males & 392 & 46 & 11 & 43 \\
Secondary School Females & 39 & 46 & 18 & 36 \\
College Males & 199 & 45 & 20 & 35 \\
\hline
\end{tabular}

to consider them in the bright moonlight. ...All of the tapering cylinders were over five feet long, and the largest of them towered over twenty feet. ...A tremendous gallery of erect male members, every-one loaded and ready to fire. All circumcized. For uncounted decades and centuries, they had been aimed at heaven, enduring seasonal rains and storms. ....Men had long sought the Elephant's Graveyard and King Solomon's Mines, the Golden Fleece of Jason, and the fabled delights of the Old Man's Garden, where Assassins were trained. But this was the ultimate secret, the fierce and fecund heart of Africa, where all the unspent orgasms of the world were honoured." See Attlee, The Judah Lion Contract (Greenwich, Conn.: Fawcett Publications, 1972) pp. 81-82.

9 This work was conducted by Dr. William Shack, an American anthropologist who worked in Ethiopia for a while, and is now at Berkeley. The study is cited by Levine.

10 See Donald N. Levine, op. cit., p. 22, and Levine, Wax and Gold: Tradition and Innovation in Ethiopian Culture (Chicago: University of Chicago Press, 1965), p. 143. 
Table 2

Attitudes of International Sample of College Students toward War

\begin{tabular}{lcccc}
\hline & & \multicolumn{3}{c}{ War is } \\
\cline { 3 - 5 } & & $\begin{array}{c}\text { Needless and } \\
\text { Preventable } \\
\%\end{array}$ & $\begin{array}{c}\text { Necessary } \\
\text { Evil } \\
\%\end{array}$ & $\begin{array}{c}\text { Sometimes a } \\
\text { good thing } \\
\%\end{array}$ \\
\hline France & 105 & 65 & 26 & 9 \\
Israel & 28 & 68 & 18 & 14 \\
Japan & 95 & 72 & 16 & 8 \\
Mexico & 106 & 51 & 23 & 26 \\
\hline
\end{tabular}

associated with manly virility and contrasted with weakness, a quality which though despised is held to possess a certain, compensating mystical virtue."11

When the link between masculinity and aggressiveness is so close, almost any weapon of war becomes by definition a phallic symbol as well. The associations between combat and sexual conquest are so intimate that an easy psychological transition takes place between martial and sexual symbolism.

The war dances in many African societies become also phallic dances. Many African dances fuse the aesthetic and the athletic. The grand leap, the stamping of the feet, the vigorous movements of the warrior's body, all acquire both sexual and martial suggestiveness.

Sometimes fertility dances share movements with war dances. The orientation towards reproduction becomes interlinked with the mystique of brave destruction. Again the range of elements which feature in such dances are from chest thumping to thunderous imitations of the copulation of beasts.

In many a context, the African dancer becomes himself a phallic symbol. In the words of Lawino,

\footnotetext{
"It is danced in broad daylight

In the open

You cannot hide anything...

All parts of the body

Are shown in the arena!

Health and liveliness

Are shown in the arena!'12
}

The dancer, the warrior, the lover, become indistinguishable where the heritage of imagery draws no sharp distinction between valor and virility.

\section{The Warrior and Society}

African societies differed in their modes of self-defence and security arrangements, and are certainly different in their conceptions of the rights and

11 I. M. Lewis, "The Politics of the 1969 Somali Coup", The Journal of Modern African Studies, Vol. 10, No. 3, October 1972, pp. 389-390.

12 Okot p'Bitek, Song of Lawino, (Nairobi: East African Publishing House, 1966) p. 34. 
duties of the warrior. But certain themes have persisted in cultures within the African continent which are otherwise very different from each other. This is partly because the concept of the warrior captures some quite fundamental aspects of human organization and human symbolism. Pre-eminent among the more obvious shared aspects is, firstly, the link between the warrior and idea of adulthood; and secondly, the link between the warrior and the concept of manhood. These are quite fundamental linkages and carry a variety of implications. ${ }^{13}$

Adulthood is related to notions of self-reliance. The adult is he who has a capacity to earn his own living and maintain his own homestead. But adults are sometimes to be differentiated from elders. In this sense, while children are pre-adults elders are post-adults, no longer at the peak of their physical powers, though hopefully much enhanced in their mental powers. African languages differ in the way they handle the distinction between relatively young adults, with warrior duties, on the one hand, and elders, on the other.

But even if we use the term adult in its usual sense in the English language, to indicate those who are no longer children, the basic point remains that it is from the ranks of adults that full warriors are recruited. One became a warrior when one was presumed to be capable of protecting cattle, or defending land, or collectively fighting to protect the clan. A heavy element of self-reliance was thus built into the concept of warrior because of its link with the concept of adulthood.

In many African societies the process of initiation carried implications of this presumed stage of self-reliance. The generations are separated for a while. The young adults are separated from their elders. In this respect there is sometimes a closer bond between the third generation and the first, between the elders and the children, than there is between the elders and the young adults. Many African societies encourage newly grown boys to live separately in a lodge after puberty.

"The removal of the boy from parental care is a matter of separation of the generations. The boy is developing into a man, a new generation has come into being within the family. This is on an individual level. Seclusion of the whole group of initiands in their own lodge, and their reluctance to give the fathers, i.e. the parental generation, access to the lodge, also points to the separation of adjacent generations, but on a group level. The

13 For the latest debate concerning the warrior tradition and resistance to colonial rule consult T. O. Ranger, "African Reactions to the Imposition of Colonial Rule in East and Central Africa," in L. H. Gann and Peter Duignan, The History and Politics of Colonialism, 1870-1914, Vol. I (Cambridge, 1969) pp. 293-324; John Illife, Tanganyika under German Rule, 1905-1912 (Nairobi and Cambridge, 1969); Terence Ranger, "Connexions between 'Primary Resistance' Movements and Modern Mass Nationalism in East and Central Africa," Parts I and II, Journal of African History, Vol. IX, Nos. 3 and 4, 1968, pp. 437-453 and 631-641. Consult also Michael Crowder, West African Resistance (Ibadan, 1970); and Robert I. Rotberg and Ali A. Mazrui (editors) Protest and Power in Black Africa (New York, 1970) ; Terence Ranger, "The 'New Historiography' in Dar es Salaam: An Answer," African Affairs, Vol. 70, No. 278, January 1971, pp. 50-61. 
'oneness' of the circumciscd in the lodge would seem to express the solidarity of a new adult generation...."14

The gulf between the parental generation and the generation of the new adult has its own tensions. Alnaes tells us about Konzo fathers who are reluctant to have their sons circumcised "too soon". This is because the circumcision ceremony converts a son in some sense into a rival in adulthood. Among the Konzo a boy eager to cross the line into adulthood might in desperation go to a Muslim to be circumcised without going through the traditional Konzo ritual. But this is a last resort. A better strategy in the face of a reluctant father is to run away and be circumcised in the traditional manner before the father manages to intervene.

"... a fair number of boys run away to be circumcised in the traditional manner and they usually manage to have the operation before the father arrives on the scenc... The traditional circumcision is a symbolic transition from childhood to manhood."15

African societies with age-grade systems have more complex stages of social progression. The Nandi of Kenya have seven age-grades, each with a name of its own, and all operating on the basis of a recurring cycle. Every fifteen years the fighting age hands over to the age next below it. And members of that succeeding age would have been preparing themselves for the previous fifteen years to qualify for warriorhood after circumcision. The retiring age moves up to become elders. ${ }^{16}$

The theme of mature independence again links adulthood with warriorhood. The initiation ceremonies, both those involving circumcision and those which do not, share certain important characteristics. S. N. Eisenstadt has summarized the descriptions of these ceremonies as they abound in the literature. We might use here Eisenstadt's summary, but relate it more explicitly to the theme of self-reliance and mature independence which initiation implies:

(a) In these ceremonies the pre-adult adolescents are transformed into full adult members of the tribe, the transformation being effected through

(b) a series of rites in which the adolescents are symbolically divested of the characteristics of youth and invested with those of adulthood from a sexual and social point of view. This symbolic investment, which has deep emotional significance, may have various concrete manifestations, bodily mutilation, circumcision, taking on of a new name, symbolic rebirth, etc.;

14 Although this description refers specifically to the Konzo it also applies to a large number of similar cultures in Africa. For this particular quotation consult Kirsten Alnaes, "Nyamayingi's Song: An Analysis of a Circumcision Song," Africa, Vol. XXXVII, No. 4, October 1967, p. 460.

15 Ibid. pp. 458-459.

16 G. W. Huntingford, The Nandi of Kenya (London, 1953); A. C. Hollis, The Nandi, Their Language and Folklore (London, 1909) and E. E. Evans-Pritchard, "The Political Structure of the Nandi-Speaking People of Kenya," Africa, Vol. XIII, 1940, pp. 250-268. 
(c) the complete symbolic separation of the adolescents from the world of their youth, and especially from their close status attachments to their mothers; i.e. their complete "male" independence and autonomous male image are articulated (the opposite usually holds true of girls' initiations);

(d) dramatization of the encounter between the different generations, a dramatization which may take the form of a fight, competition, etc., and which the basic complementariness - whether of a continuous or discontinuous type - is stressed; thus, in all initiation rites the members of different generations must act together, the ones as teachers, the others as "students". The elders sometimes assume frightening forms and stress that without them the adolescents cannot become adults. Quite often the discontinuity between adolescence and adulthood is symbolically expressed in the "rebirth" of the adolescent - in their symbolic death as children and rebirth as adults. ${ }^{17}$

Those communities in Africa which have had age-set systems have usually done so in relation to the military organization of the tribe. But even among the Nuer, where the age-set system is less directly militaristic, the link between adulthood, manhood, and warrior remains explicit. In Eisenstadt's words:

"When a boy passes into the grade of manhood his domestic duties and privileges are radically altered. From being everybody's servant and an inferior, he becomes an independent adult. This change of status is epitomized in the taboo on milking through which he becomes separated from women, with whom he was identified as a boy-a taboo which bcgins at his initiation and remains in effect throughout his life. ...At initiation the youth receives a spear from his father or uncle and becomes a warrior. ... He becomes a true 'man' when he has fought in war (battle) and has not run away, has duelled with his age mate, has cultivated his garden and has married." 18

We hope to demonstrate later that the theme of self-reliance involved in this warrior tradition is antithetical to the dependency complex which many Africans later acquired under the impact of colonial rule. We hope also to illustrate that the struggle against dependency as exemplified by Field Marshal Amin at his best is, in an important sense, a reactivation of the ancestral assertiveness of warrior culture.

What should not be overlooked is again the sexual dimension of the warrior culture. As we indicated, an initiation ceremony was simultaneously a moment of confirmation as an adult and graduation as a man. Adulthood and manhood were sometimes indistinguishable for the male line of the tribe.

\section{Military Technology and the Persistence of Masculinity}

In the history of military technology, there was no doubt a time when muscle was directly relevant for combat effectiveness. How effectively a fighter

17 S. N. Eisenstadt, From Generation to Generation: Age Groups and Social Structure (New York: The Frce Press, 1971 edition) pp. 31-32.

Ibid. p. 60 . 
wielded his rungu or his axe, how far he threw his boomerang or spear, how totally he dislocated the jaw of his opponent, were all partly determined by the physical strength and physiological prowess of the fighter. But as military technology advanced, pure muscle became less relevant. The preponderance of men in the fighting profession became less justifiable in terms of the muscular technology of combat. To press the button of a B-52 on a bombing mission over North Vietnam was an assignment which did not need a man's finger. Yet the great majority of those who fought in the Vietnam war were men.

Technology may change many aspects of culture, but so far it has not yet fundamentally changed that part of culture which assigns the warrior-role disproportionately to men.

Is the explanation biological or cultural? Are men more violent because of upbringing and socialization or because of higher biological aggressivity in their nature?

Experiments have indicated a definite difference in levels of aggressivity between male and female in other creatures.

The political power of men can perhaps be traced to their preponderance in the military profession from very early times.

In a few countries recently, women have attained high office. But here one must distinguish between:

(a) political power by delegation

(b) political power by derivation

(c) direct political power

When Elizabeth Bagaya was Foreign Minister of Uganda, that was clearly uneven delegated power. The real authority resided in President Amin.

What about Indira Gandhi? Was her original ascent to high office partly based on the credentials that she was Nehru's daughter? Was Mrs. Bandaranaike's original ascent to power partly derived from her status as the widow of an assassinated male Prime Minister? Did Señora Peron's position emanate from her late legendary husband? If so, each of these three impressive female heads of government derived her power partly from the stature of a man she was related to.

In the recent history of women in power, perhaps only Mrs. Golda Meir attained supreme authority without the prestige of a towering male relative. Her authority while it lasted was neither delegated (like Bagaya's) nor derivative (like Mrs. Gandhi's, Mrs. Bandaranaike's or Isabella Peron's) but direct.

A major reason behind the relative powerlessness of women in politics may lie in their military impotence. Sexual division of labour had reserved the role of the warrior disproportionately for the male of the species. In so doing it also helped to reserve the role of the ruler for the male also.

In the African colonies a great experimental opportunity was missed this century. Why did not the British and the French imperial governments create colonial armies made up of African women? The experiment could have been 
of immense value for the human race as a whole. Since the imperial powers were disrupting local cultures in other ways in any case, it might have made sense also to attempt a disruption in one of the most perennial and obstinate aspects of human culture - the masculinity of warriorhood.

Indeed, as indicated in another chapter in this collection, the French even helped to destroy in the nineteenth century that rare female class of warriors, the Amazons of Dahomey. In the process of colonizing Dahomey (now the Republic of Benin), the French shattered Dahomey's most distinctive institution.

Elsewhere in their colonies the French were no different from the other European colonial powers - they all missed an opportunity for the kind of social engineering which would have effectively enlisted African women to the profession of arms.

Such an imperial experiment might not have worked in every African country. But if it worked in any of them at all, the consequences for African politics after independence could have been epoch-making. The soldiers who took over power after independence would in some cases have been women. And some of the presidents in uniform at meetings of the Organization of African Unity would therefore have come from the female half of Africa's humanity. African women in control of armies could have started a unique experiment in the sharing of power.

This brings us to the connection between democracy and military technology. There are African societies to the present day where military skills are still assessed in terms of prowess of handling spears and in the use of the bow and arrow. The simplicity of this technology made it accessible to almost every one. In the words of the British anthropologist, Jack Goody:

\footnotetext{
"The bow and arrow is essentially a democratic weapon; every man knows how to construct one; the materials are readily available, the techniques uncomplicated, the missiles easy to replace (though more difficult with the introduction of iron that affected even hunting people like the Hadza of Tanzania and the Bushmen of the Kalahari). With the technologies of the bow and stone-tipped arrow any kind of centralization is almost impossible. But with the introduction of metals, kingdoms are on the cards."19
}

In the case of the original West African kingdoms it was, according to Goody, the uneven distribution of raw materials which involved systems of exchange and brought about often long distance trade. This in turn necessitated systems of control and security.

With the coming of the rifle in colonial Africa, and the tank in independent Africa, military elitism became more conspicuous. The old days of military democracy, when everyone passed through the warrior stage, and when the weapons were the simple ones capable of being manufactured by the warrior himself, were now replaced by the era of military professional specialists, with weapons requiring high technological skill to manufacture and specialized training to use.

19 Jack Goody, Technology, Tradition and the State in Africa, (London, 1971) : pp. 43-46. 
But even in the days of the more democratic bow and arrow, women in almost all African societies were left out of combat. Only an imperial power with a higher military technology could have started quickly enough the process of militarizing womanhood. African women in charge of tanks and artillery under the colonial regimes would have been potential wielders of political power after independence.

It so happens that colonial armies were often recruited from some of the least privileged ethnic communities in Africa and from some of the most peripheral regions. There was a belief among most colonial administrators that illiterate or semi-literate Africans made better soldiers than the better educated. The better educated was sometimes distrusted as "cheeky" and not adequately obedient.

In any case, the better educated young men had other ambitions. A job as a soldier even in modern uniform - with guns rather than spears and bows and arrows - was seldom the most attractive option for an ambitious African youth. White collar work often ranked much higher.

The British and the French therefore bequeathed to their former colonies military establishments manned primarily by people recruited from some of the poorest and least influential sections of the population. When these finally took over power after independence, some balance was partially restored in their societies. The intelligentsia and the former bourgeoisie still remained influential, but no longer paramount. The lumpen-militariat had successfully (and sometimes brutally) claimed a share of the power.

Unfortunately, this lumpen-militariat was almost exclusively made up of men. On the basis of ethnic balance in the sharing of power, their triumph in places like Nigeria and Uganda had some democratic consequences. Previously deprived communities entered the main stream of national life. But from the point of view of restoring balance between men and women, the lumpenmilitariat which colonialism created contributed nothing to the resolution of sexual injustice. The very fact that the colonial recruiting officers often insisted on physical height of five feet eight inches $\left(5^{\prime} 8^{\prime \prime}\right)$ as a qualification for joining the army aggravated the discrimination against female recruits.

But given that a great experimental opportunity was lost in Africa, are there signs of a change in the future? Field Marshal Idi Amin's female "suicide squad" is at least symbolic of some basic rethinking about the role of women in war. This rethinking may have started among otherwise relatively traditionalist groups in Africa.

Less traditionalist circles include the new rulers of independent Mozambique and the experimentation in female recruitment which FRELIMO inaugurated while it was still fighting Portuguese colonial rule, and has maintained since.

It is unlikely that male political dominance in the world as a whole will end this century. But a step in that direction has to include the increasing militarization of womanhood. This may be a sad reflection on the human race. It is certainly a reflection of the historical linkage between statehood and the control of 
physical force, between politics and the instruments of coercion, between power and warriorhood. Military technology is now too sophisticated to be as democratic as the bow and arrow. But it is at least sophisticated enough to make physical height and muscle power no longer relevant in recruiting for the armed forces. While military technology is now elitist in terms of the skills needed, it is at the same time more sexually neutral than ever before. The primeval war of the sexes is about to enter its most fundamental stage ever.

Some steps have already been taken in a number of countries to deal with this potential social crisis. Promotion of women in the American armed forces has been accelerated. The Soviet Union and Israel have attempted to consolidate their relative "equal opportunity" policies. The Egyptian army is using more women than ever before.

But there is no room for complacency. On the contrary, some of the current shifts of power in the world may be aggravating the problem. The energy crisis from 1973 onwards aroused the hopes of the people of the Third World. The Organization of Petroleum-Exporting Countries had demonstrated how "primary producers", technologically underdeveloped, could put pressure on the industrial giants. Since then the movement for the creation of a new international economic order has gathered momentum, led partly by members of OPEC.

But if the politics of oil show a shift of power in favour of at least some Third World countries, that same shift is in favour of countries which are still more "male-dominated" than average. Saudi Arabia, the most influential of the OPEC countries, also has a social system in which women are not only demilitarized but also depoliticized. Most of the Gulf states have basically similar social systems. So does Iran by and large.

The Third World has good reason to celebrate the emergence of OPEC and oil power. But do the women of the world have similar reasons for rejoicing? Is not the balance of influence shifting in favour of greater masculinity as illustrated in the social structures of OPEC countries?

It is too early to be sure. The new prosperity of the oil-exporting states may gradually lead not only to the politicization of their women, but also to their militarization.

What is clear is that momentous changes are about to occur. How those changes will affect the interaction between sex and war, between technology and stratification, are questions whose answers still lie in the womb of future history. 